\title{
A technical discussion of the emission of ammonia from SI vehicles fitted with three-way catalysts
}

\begin{abstract}
Ammonia emissions from motor vehicles have risen significantly in recent decades, due to the rollout of three-way catalysts within the spark ignition vehicle fleet. Vehicular ammonia emissions are currently unregulated, even though ammonia is harmful for a variety of reasons, and the gas is classed as toxic. Having reached its light-off temperature, a three-way catalyst can produce substantial quantities of ammonia through various reaction pathways. Emission is markedly higher during periods where demand for engine power is higher, when the engine will be operating under open-loop conditions. The air-to-fuel ratio, cylinder temperature and rate of formation of carbon monoxide and nitrogen monoxide all correlate to varying degrees with ammonia production. Ammonia emissions could represent a serious threat to air quality, particularly in urban settings. Further investigation is imperative to minimise the risks posed by this as yet unregulated exhaust emission component.
\end{abstract}

Keywords: ammonia, $\mathrm{NH}_{3}$ emission, spark-ignition engine, three-way catalyst, air quality

\section{Analiza emisji amoniaku z samochodów z silnikami o zapłonie iskrowym wyposażonych w trójfunkcyjny reaktor katalityczny}

\begin{abstract}
Emisja amoniaku z pojazdów samochodowych znacząco wzrosła w ciagu kilku ostatnich dekad, co spowodowane było wzrostem liczby samochodów z silnikami o zapłonie iskrowym, wyposażonych $w$ trójfunkcyjne reaktory katalityczne. Emisja amoniaku z pojazdów nie jest obecnie objęta regulacjami prawnymi, pomimo iż amoniak jest szkodliwy dla organizmów żywych i gaz ten zaklasyfikowany jest jako toksyczny. Osiagając temperaturę pracy (light-off), trójfunkcyjny reaktor katalityczny może wytwarzać znaczne ilości amoniaku w wyniku różnych reakcji chemicznych. Emisja ta jest zauważalnie wyższa podczas stanu pracy silnika, gdy zapotrzebowanie na moc jest większe, przy sterowaniu silnika z pominięciem sygnału z sondy $\lambda$. Stosunek powietrze-paliwo, temperatura w komorze spalania, szybkość formowania się tlenku węgla CO i tlenku azotu NO wpływaja w znaczacym stopniu na powstawanie amoniaku. Emisja amoniaku może powodować istotne zagrożenie dla jakości powietrza, szczególnie w obszarach miejskich. Ciagłe badania sq konieczne, by zminimalizować ryzyko spowodowane ta emisja, z uwagi na brak odpowiednich wymagań w przepisach dotyczacych emisji związów szkodliwych spalin.
\end{abstract}

Slowa kluczowe: amoniak, emisja $\mathrm{NH}_{3}$, silnik o zapłonie iskrowym, reaktor trójfunkcyjny, jakość powietrza

\section{Introduction}

Although long recognised as an automotive exhaust gas component [1] (first systematically studied in 1967 [2]), ammonia $\left(\mathrm{NH}_{3}\right)$ is one of a group of exhaust gases that has received relatively little attention in comparison to $\mathrm{CO}, \mathrm{NO}_{\mathrm{x}}$, $\mathrm{CO}_{2}, \mathrm{HC}$ etc, a status reflected in past and current exhaust emissions regulation legislation. Currently unregulated in the European and US markets, it belongs to a group of compounds which may feature in future regulations regarding exhaust emissions from light duty vehicles [3].

In the atmosphere, $\mathrm{NH}_{3}$ plays a significant role in the formation of secondary particulate matter (PM) $[1,4-10]$. Secondary PM is formed by the reaction of molecules in the air to form particles - rather than PM being created directly at source ('primary PM'). In Europe, 50 to 90 per cent of PM10 and around 50 per cent of PM2.5 is formed in this way [5]. Ammonia is known to react with nitrogen compounds and acids to produce PM $[5,7,11]$. Several ammonia-based PM formation reactions are irreversible and occur at ambient temperatures [11]; the formation of aerosols such as ammonium sulphate and ammonium nitrate depends

\section{Wstęp}

Amoniak $\left(\mathrm{NH}_{3}\right)$, który był dawno uznany za składnik spalin samochodowych [1] (pierwsze szczegółowe opracowanie powstało w 1967 r. [2]), należy do grupy gazów spalinowych, którym poświęcono zdecydowanie mniej uwagi niż $\mathrm{CO}$, $\mathrm{NO}_{x}, \mathrm{CO}_{2}, \mathrm{HC}$ itp., co odzwierciedlają wcześniejsze i obecne przepisy dotyczące emisji związków szkodliwych spalin. Obecnie poziom emisji amoniaku jest nieuregulowany przepisami na rynku europejskim i amerykański, należy on jednak do grupy związków, które mogą być objęte limitami w przyszłych przepisach dotyczących emisji z pojazdów samochodowych [3].

W atmosferze $\mathrm{NH}_{3}$ odgrywa znaczącą rolę w procesie formowania się cząstek stałych (PM) [1,4-10]. Cząstki stałe tego typu formowane są $\mathrm{w}$ reakcjach molekuł w powietrzu, tworząc cząstkę - inaczej niż PM powstałe bezpośrednio u źródła (,pierwotne PM”). W Europie, 50 - 90\% cząstek PM10 i około 50\% PM2.5 powstaje w ten sposób [5]. Wiadomo, iż amoniak reaguje ze związkami azotu i kwasami, tworząc cząstki stałe $[5,7,11]$. Kilka reakcji tworzenia PM opartych na amoniaku jest nieodwracalnych i zachodzi w 
strongly on the availability of ammonia [5]. Ammonia has a short atmospheric residence time and rarely travels far from source as $\mathrm{NH}_{3}[1,8]$ - concentrations are roughly some 90 per cent lower 10 metres from roadside [12]. However, the secondary $\mathrm{PM} \mathrm{NH}_{3}$ produces can travel much further, and is widely recognised as being able to affect human health, damage vegetation and building materials and cause acidification and eutrophication of surface waters $[6,13-17]$. Ammonia is classified as a toxic pollutant $[6,7,13,18,19]$.

A UNECE protocol [17] and an EU directive [14] set limits for total $\mathrm{NH}_{3}$ emissions from EU member states, but have no specific quotas for the transport sector [15].

Active catalytic systems fitted to the latest Dieselpowered vehicles use urea to produce the ammonia required for selective catalytic reduction (SCR) [20, 21]. The escape of ammonia from such a system is called 'ammonia slip', and is undesirable because of the effects listed above. Euro 6 legislation contains specific limits for vehicles with SCR systems in recognition of the deleterious effects of $\mathrm{NH}_{3}$ emissions. The proposed limit is $10 \mathrm{ppm}[20,22]$. The Euro 6 SI proposal contains no mention of ammonia.

Ammonia is a natural atmospheric trace gas [8, 23], but certain anthropogenic sources are significant. While intensive agriculture, sewage treatment and the use of fires to clear forested land are major anthropogenic sources, vehicles equipped with three-way catalysts (TWCs) also contribute [1, 3-8, 12, 15, 16, 19, 24-28]. Ambient levels of ammonia have increased [16], even when taking into account increases in traffic volumes [8]. Measurements taken several years apart in Manchester (UK), indicate a 40 per cent increase in ammonia concentration, relative to concentrations of $\mathrm{NO}_{x}$ and $\mathrm{CO}$. This shows that increased traffic volumes are not the cause; rather the fitting of TWCs to vehicles is causing these increased levels of ammonia emission [8]. Other studies have found that even as emissions of regulated compounds have fallen, $\mathrm{NH}_{3}$ emission from traffic appears to have risen [24]. Despite the fact that the emission of ammonia is normally associated with agricultural activities, areas with heavy/regular traffic have been found to show higher concentrations of $\mathrm{NH}_{3}$ than rural areas with only light/occasional traffic $[23,28]^{3}$. Studies performed in tunnels and on large arterial roads may drastically underestimate rates of ammonia emission from SI vehicles, as the relatively static, low-acceleration driving observed is not conducive to ammonia formation [15]. Ammonia emission factors from SI vehicles may have risen by as much as two orders of magnitude in the past 30-40 years $[16,24]$, due to the massive increase in the proportion of vehicles in the SI fleet featuring TWCs during this period.

Ammonia is one of a number of simple nitrogen compounds emitted by modern SI vehicles. Ammonia and $\mathrm{NO}_{\mathrm{x}}$ readily participate in a wide range of reactions at ambient conditions earning them the appellation reactive nitrogen compounds (RNCs) $[6,7]$. Ammonia can be seen as an intermediate between $\mathrm{NO}_{x}$ and a simple hydrocarbon and as temperaturze otoczenia [11]; tworzenie aerozoli, takich jak siarczan (VI) amonu i azotan (V) amonu bardzo uzależnione jest od dostępności amoniaku [5]. Amoniak w atmosferze jest nietrwałym związkiem i rzadko występuje $\mathrm{z}$ dala od źródła emisji, jako $\mathrm{NH}_{3}[1,8]$ - zawartość amoniaku w atmosferze jest około $90 \%$ mniejsza w odległości $10 \mathrm{~m}$ od pasa przydrożnego [12]. Jednakże PM powstałe z udziałem $\mathrm{NH}_{3}$ mogą docierać dalej i są szeroko znane jako cząstki mające negatywny wpływ na zdrowie człowieka, zakłócające wegetację roślin i niszczące materiały budynków, powodujące zakwaszenie i eutrofizację wód powierzchniowych [6, 13 - 17]. Amoniak zaliczany jest do gazów toksycznych zanieczyszczających atmosferę $[6,7,13,18,19]$.

Protokół Europejskiej Komisji Gospodarczej Organizacji Narodów Zjednoczonych (EKG ONZ) [17] i europejskie dyrektywy nakładają ograniczenia na całkowitą emisję amoniaku dla członków Unii Europejskiej, ale bez specjalnego rozdziału na udział sektora transportowego [15].

Selektywne katalityczne systemy (SCR), będące wyposażeniem pojazdów z nowymi silnikami o zapłonie samoczynnym (ZS), wykorzystują mocznik do produkcji amoniaku potrzebnego do selektywnej redukcji katalitycznej (SCR) [20, 21]. Wydostanie się amoniaku, który nie wzią1 udziału w reakcji redukcji, z tych systemów na zewnątrz układu wylotowego nazywane jest ,ammonia slip” i jest niepożądane z powodów szkodliwych skutków wspomnianych wcześniej. Przepisy normy Euro 6 zawierają specjalny limit dla pojazdów z systemem SCR, w związku ze szkodliwymi efektami emisji $\mathrm{NH}_{3}$. Proponowany limit to $10 \mathrm{ppm}[20,22]$. Propozycje limitów związków szkodliwych w normie Euro 6 dla pojazdów z silnikami ZI nie dotyczą amoniaku.

Amoniak w środowisku naturalnym występuje w śladowych ilościach $[8,23]$, ale pewne źródła emisji pochodzenia antropologicznego odgrywają znaczącą rolę. Głównymi źródłami antropologicznymi są intensywne uprawy rolne, oczyszczalnie ścieków i używanie ognia przy wycinaniu lasów. Pojazdy wyposażone w trójfunkcyjne reaktory katalityczne TWC także są zaliczane do źródeł emisji amoniaku [1, $3-8,12,15,16,19,24-28]$. Poziom zawartości amoniaku w powietrzu wzrósł [16] ze względu na wzrost wielkości natężenia ruchu pojazdów [8]. Pomiary prowadzone przez kilka lat w Manchesterze (Wielka Brytania) wykazały 40-procentowy wzrost stężenia amoniaku w porównaniu do zmian stężenia $\mathrm{NO}_{\mathrm{x}}$ czy CO. Pokazuje to, że wzrost wielkości natężenia ruchu drogowego nie jest główną przyczyną tego zjawiska, a raczej odpowiada za to wyposażenie pojazdów w trójfunkcyjne reaktory katalityczne, które przyczyniają się do zwiększonych poziomów emisji amoniaku [8]. Inne badania wykazały nawet, że podczas spadku emisji związków objętych limitami prawnymi, emisja $\mathrm{NH}_{3}$, pochodząca ze źródeł związanych z transportem, wzrastała [24]. Pomimo tego, iż emisja amoniaku zwyczajowo uważana jest za powiązaną z działalnością rolnictwa, obszary o dużym natężeniu ruchu pojazdów okazały się miejscami o większym stężeniu $\mathrm{NH}_{3}$ w powietrzu, niż w przypadku terenów wiejskich i/lub o mniejszym natężeniu ruchu [23, 28]. Wyniki badań przeprowadzonych w tunelach i wzdłuż dużych arterii drogowych 
such forms part of a continuum of species whose emission should be reduced as far as is practicable.

Much of the nitrogen in the intake air is unaffected by the combustion process and simply passes through the powertrain; some reacts to produce various RNCs both in the engine out flux and in the TWC (Fig. 1). The relative proportions of these gases is by no means fixed, and concentrations of these species can vary by orders of mogą nie doceniać poziomu emisji amoniaku z pojazdów z silnikami ZI, gdyż względnie statyczny i spokojny sposób jazdy, bez gwałtownych przyspieszeń, nie prowadzi do tworzenia się amoniaku [15]. Globalna emisja amoniaku z pojazdów z silnikami ZI mogła wzrosnąć nawet dwukrotnie w przeciągu ostatnich 30 - 40 lat $[16,24]$, ze względu na znaczny wzrost udziału pojazdów mających układy wylotu spalin wyposażone w trójfunkcyjny reaktor katalityczny.

Amoniak jest jednym z wielu prostych związków azotowych emitowanych przez współczesne pojazdy z silnikami ZI. Amoniak i $\mathrm{NO}_{\mathrm{x}}$, bez trudu uczestnicząc w wielu reakcjach w warunkach otoczenia, tworzą grupę reaktywnych związków azotu (reactive nitrogen compounds RNC). Amoniak może być uznawany jako produkt pośredni reakcji między NO magnitude from second to second. The theoretical goal for emissions control regarding RNCs would be for all nitrogen to leave the vehicle in the inert $\mathrm{N}_{2}$ form [15]. The proportion of $\mathrm{NH}_{3}$ in the exhaust can be thought of as an inverse measure of how well the catalyst reduces $\mathrm{NO}_{x}$ to $\mathrm{N}_{2}$. Higher proportions of $\mathrm{NH}_{3}$ indicate a general overreduction of $\mathrm{NO}_{x}$.

Ammonia $\left(\mathrm{NH}_{3}\right)$ and nitrogen monoxide (NO) are the main outputs of reactive nitrogen compounds from a TWC [7, 15, 29]; release of RNCs should be reduced as far as possible.

The proportion of nitrogen atoms which leave the TWC in the form of $\mathrm{NH}_{3}$ appears to vary by an order of magnitude for vehicle speeds $0-145 \mathrm{~km} / \mathrm{h}$ (Fig. 2). Two regimes are clearly visible. At engine out temperatures above $300{ }^{\circ} \mathrm{C}$, proportions rarely exceed 5 per cent. While at lower speeds the elimination of NO was less efficient, more of the output was in the form of $\mathrm{NH}_{3}$. From Figure 2 it can be seen that on average, the $\mathrm{NH}_{3}$ fraction decreases by roughly 3 per cent for each $10^{\circ} \mathrm{C}$

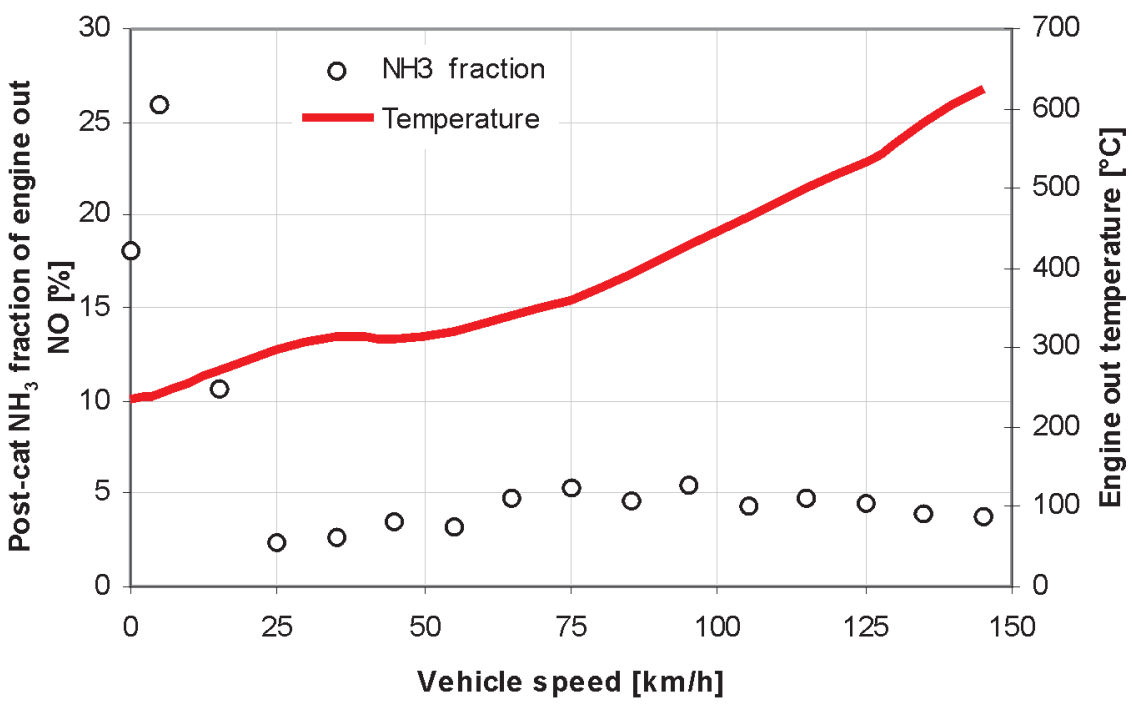

Fig. 2. Percentage $\mathrm{NH}_{3}$ mass fraction (the percentage of the mass of NO eliminated in the TWC which can be accounted for by the mass of $\mathrm{NH}_{3}$ emitted) as a function of vehicle speed (data from [19])

Rys. 2. Procentowy udział masowy $\mathrm{NH}_{3}$ (procentowa masa zredukowanego $\mathrm{NO}$ w reaktorze trójfunkcyjnym, która może być odpowiedzialna za masowa emisję $\mathrm{NH}_{3}$ ) w funkcji prędkości pojazdu [19] 
increase (with $\mathrm{R}^{2}=0.83$ ), up to $300{ }^{\circ} \mathrm{C}$. This hints at $\mathrm{NH}_{3}$ formation reactions which can occur at temperatures below $300{ }^{\circ} \mathrm{C}$, even if the quantities formed in this way are very small. Species which are known to be formed to make up the rest of the nitrogen balance are $\mathrm{N}_{2}, \mathrm{NO}_{2}$ and also $\mathrm{N}_{2} \mathrm{O}$ $[16,29]$. Isocyanate and isocyanic acid, ammonium thiocarbamate and other species [2] (including more complex nitrogen compounds) may also be emitted, but in very limited quantities.

\section{Formation of ammonia in a three-way catalyst}

Formation of $\mathrm{NH}_{3}$ within cylinders and non-catalytic exhaust systems has long been known to be very limited [2, 19]. Data presented in [19] show post-catalyst $\mathrm{NH}_{3}$ emission factors to be $\sim 100$ times larger than engine out readings, but with no correlation between these data $\left(\mathrm{R}^{2} \approx 0\right)$. Three-way catalysts can catalyse a number of unintended side-reactions [16]. These side reactions include the steam reforming and water-gas shift reactions, both of which produce hydrogen $[15,16]$, which can participate in further reactions to produce ammonia.

There are multiple known and proposed $\mathrm{NH}_{3}$ formation pathways, both relatively direct (e.g. Eq. (2)) and highly indirect (involving many intermediates) (e.g. Eqs. (6a) - (6c)) and these processes remain under investigation. Precious metal loading, space velocity, temperature, $\lambda$ and fuel sulphur content can also all influence formation of $\mathrm{NH}_{3}$ to varying degrees. Some simplified ammonia formation reactions which have been suggested are as follows:

\begin{tabular}{|c|c|c|}
\hline $\begin{array}{c}\text { Ammonia formation reaction/reakcje } \\
\text { powstawania amoniaku }\end{array}$ & $\begin{array}{l}\text { Eq. No./ } \\
\text { numer } \\
\text { równania }\end{array}$ & $\begin{array}{l}\text { Source/ } \\
\text { źródto }\end{array}$ \\
\hline $2 \mathrm{NO}+5 \mathrm{CO}+3 \mathrm{H}_{2} \mathrm{O} \rightarrow 2 \mathrm{NH}_{3}+5 \mathrm{CO}_{2}$ & (2) & [30] \\
\hline $2 \mathrm{NO}+5 \mathrm{H}_{2} \rightarrow 2 \mathrm{NH}_{3}+2 \mathrm{H}_{2} \mathrm{O}$ & (3) & {$[30]$} \\
\hline $2 \mathrm{NO}+2 \mathrm{CO}+3 \mathrm{H}_{2} \rightarrow 2 \mathrm{NH}_{3}+2 \mathrm{CO}_{2}$ & (4) & {$[31]$} \\
\hline $4 \mathrm{H}_{2}+\mathrm{N}_{2}+\mathrm{O}-\mathrm{R}^{\prime} \rightarrow 2 \mathrm{NH}_{3}+\mathrm{H}_{2} \mathrm{O}$ & $(5)$ & {$[21]$} \\
\hline $\begin{aligned} \mathrm{N}+\mathrm{CO} & \leftrightarrow \mathrm{NCO} \\
\mathrm{NCO}+\mathrm{H} & \rightarrow \mathrm{HNCO} \\
\mathrm{HNCO}+\mathrm{H}_{2} \mathrm{O} & \rightarrow \mathrm{NH}_{3}+\mathrm{CO}_{2}\end{aligned}$ & $\begin{array}{l}(6 a) \\
(6 b) \\
(6 c)\end{array}$ & {$[32,33]$} \\
\hline
\end{tabular}

Depending on the noble metal or metals present, intermediate species can be formed, which later undergo further reactions to produce $\mathrm{NH}_{3}$ through a series of reactions (Eqs. $(6 a)-(6 c))$.

It is perhaps that any single reaction will be the sole $\mathrm{NH}_{3}$ formation route, and different reactions probably occur under different conditions, even for the same vehicle-catalyst-fuel combination. Multiple reactions may occur simultaneously, thereby boosting the production rate. However, a certain temperature normally has to be reached before the catalyst plays a useful part in the process, analogous to an $\mathrm{NH}_{3}$ production light-off temperature. Reactions (2) and (3) can occur readily above $300{ }^{\circ} \mathrm{C}$, but depend on the engine out emissions flowing into the TWC.

There is universal agreement that rich conditions favour $\mathrm{NH}_{3}$ production $[15,17,19,30,31,33,34]$, although emis- tych związków może różnić się o rzędy wielkości z sekundy na sekundę. Teoretycznym celem ograniczenia emisji z punktu widzenia RNC jest uzyskanie takich warunków, aby cały azot opuszczał pojazd w postaci obojętnego $\mathrm{N}_{2}$. Poziom $\mathrm{NH}_{3}$ w spalinach może być traktowany jako odwrotność skuteczności reakcji redukcji $\mathrm{NO}_{\mathrm{x}}$ do $\mathrm{N}_{2}$. Większe ilości $\mathrm{NH}_{3}$ wskazują na efektywną redukcję $\mathrm{NO}_{x}$.

Amoniak $\left(\mathrm{NH}_{3}\right)$ i tlenek azotu są głównymi produktami reaktywnych związków azotu pochodzącymi z trójfunkcyjnego reaktora katalitycznego [7, 15, 29]; tworzenie RNC powinno być zmniejszone o tyle, o ile jest to możliwe.

Udział związków azotu wydobywających się z trójfunkcyjnego reaktora katalitycznego w postaci $\mathrm{NH}_{3}$ jest znacząco różny dla różnych prędkości pojazdu w zakresie od $0-145$ km/h (rys. 2). Widoczne są wyraźnie dwa obszary. Przy temperaturze spalin powyżej $300{ }^{\circ} \mathrm{C}$ udział ten rzadko przekracza 5\%, podczas gdy przy niższych prędkościach pojazdu eliminacja NO jest mniej efektywna, większa ilość atomów azotu wydostaje się w postaci $\mathrm{NH}_{3}$. $\mathrm{Z}$ analizy rysunku 2 można wywnioskować, iż średni udział frakcji $\mathrm{NH}_{3}$ spada w przybliżeniu o $3 \%$ dla każdych $10{ }^{\circ} \mathrm{C}$ wzrostu temperatury $\left(\mathrm{R}^{2}=0,83\right)$, do temperatury $300{ }^{\circ} \mathrm{C}$. To sugeruje, iż reakcje formowania $\mathrm{NH}_{3}$ mogą pojawiać się przy temperaturze poniżej $300{ }^{\circ} \mathrm{C}$, jednak ilości $\mathrm{NH}_{3}$ powstałe w ten sposób są bardzo małe. Związki powstałe, by zbilansować pozostałą ilość azotu to $\mathrm{N}_{2}, \mathrm{NO}_{2}$ i $\mathrm{N}_{2} \mathrm{O}[16,29]$. Izocyjanian i kwas izocyjanowy, tiokarbominian amonowy i inne związki [2] (łącznie z bardziej skomplikowanymi związkami azotu) mogą być również emitowane, ale w bardzo ograniczonej ilości.

\section{Powstawanie amoniaku w trójfunkcyjnym reaktorze katalitycznym}

Od dawna wiadomo, że ilość powstałego $\mathrm{NH}_{3}$ w komorze spalania silnika i układzie wylotowym, nie wyposażonym w reaktor katalityczny, jest niewielka $[2,19]$. Dane przedstawione w [19] wskazują, iż współczynnik emisji $\mathrm{NH}_{3}$ za reaktorem może być około 100 razy większy niż emisji z samego silnika, nie ma tu zależności między tymi wartościami $\left(\mathrm{R}^{2} \approx 0\right)$. W trójfunkcyjnym reaktorze katalitycznym mogą występować liczne niezamierzone reakcje uboczne [16]. Te reakcje uwzględniają reforming parowy (reakcja pomiędzy parą wodna i węglowodorami) oraz zmianę wody w gaz (deoksydacja wody przy udziale CO), w czasie których może powstawać w określonych warunkach również wodór [15, 16], który może brać udział w dalszych reakcjach, tworząc amoniak.

Jest wiele znanych i proponowanych modeli formowania się $\mathrm{NH}_{3}$ zarówno w sposób bezpośredni, jak i w znaczącej mierze pośredni (wymagający wielu produktów pośrednich) (np. równania $(6 a)-(6 c))$; obecnie procesy te są nadal badane. Zawartość metali szlachetnych, szybkość objętościowa, temperatura, współczynnik $\lambda$ i zawartość siarki w paliwie mogą również w różnym stopniu wpływać na powstawanie $\mathrm{NH}_{3}$. Niektóre uproszczone reakcje tworzenia amoniaku, o których wspomniano, przedstawiono w postaci równań (1) - (6). 


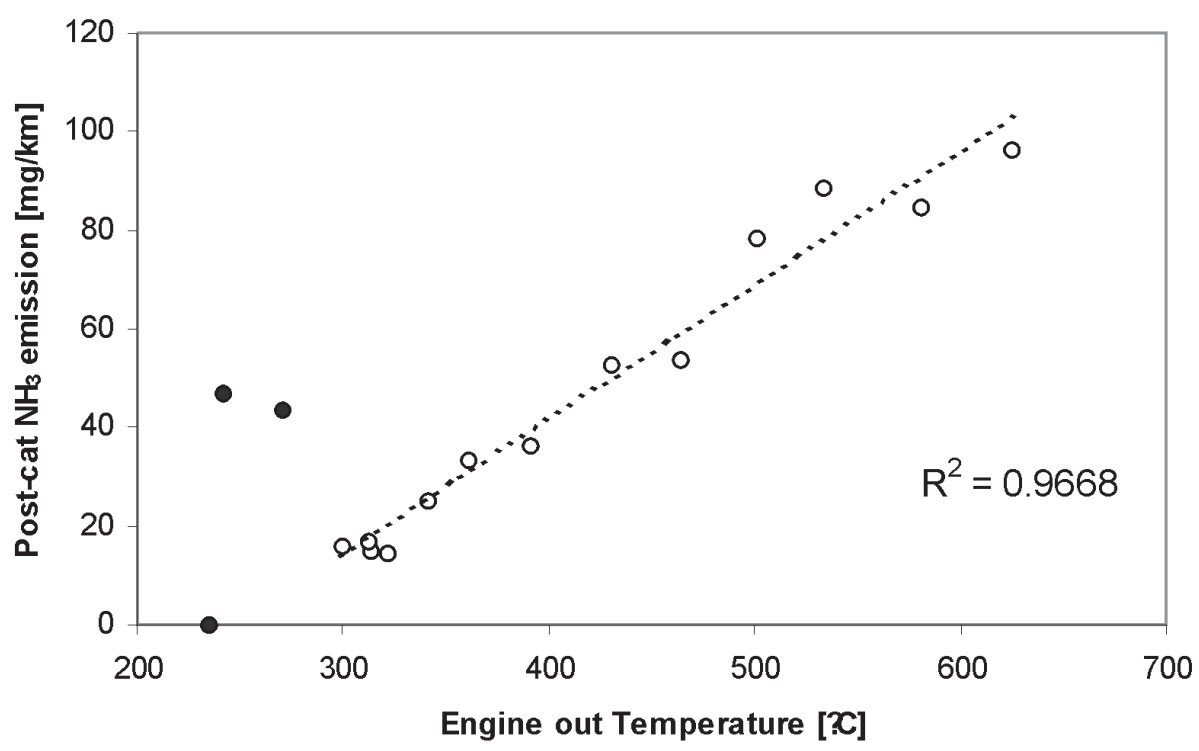

Fig. 3. Tailpipe ammonia emission as a function engine out temperature for a TWC-equipped Euro 3 vehicle for speeds $5-145 \mathrm{~km} \mathrm{~h}^{-1}$ (data from [19]). The linear regression is fitted only to data for which $\mathrm{T}>299{ }^{\circ} \mathrm{C}$; the trendline implies that $\mathrm{NH}_{3}$ emission will increase by $\sim 2.7 \mathrm{mg} / \mathrm{km}$ for every temperature increase of $10{ }^{\circ} \mathrm{C}$

Rys. 3. Emisja amoniaku z układu wylotowego spalin $w$ funkcji temperatury spalin silnikowych dla pojazdu wyposażonego w trójfunkcyjny reaktor katalityczny, spetniającego normę Euro 3 przy prędkościach w zakresie 5 - 145 $\mathrm{km} \mathrm{h}^{-1}$ [19]. Linowe przybliżenie wyników możliwe jest jedynie dla temperatur $t>299{ }^{\circ} \mathrm{C}$; linia trendu wskazuje, iż emisja $\mathrm{NH}_{3}$ będzie wzrastać o $\sim 2,7 \mathrm{mg} / \mathrm{km}$ dla każdego przyrostu temperatury o $10^{\circ} \mathrm{C}$

sion has been measured under certain lean conditions [19, 31]. Fuel-rich conditions mean the supply of reagents such as $\mathrm{CO}$ and $\mathrm{HC}$ is increased, and oxygen levels are decreased. The presence of sufficient quantities of oxygen suppresses Eq. (3) [25]. Lean operation also means hydrogen is not as active and so cracking the $\mathrm{N} \equiv \mathrm{N}$ and $\mathrm{N}=\mathrm{O}$ bonds is more difficult [21]. Ideal conditions for the production of $\mathrm{NH}_{3}$ appear to be rich, oxygen-poor, with high engine out temperatures (Fig. 3) - the conditions encountered at higher loads, particularly during periods of aggressive acceleration. A malfunctioning catalyst or faulty oxygen sensor can also make this problem worse [26].

A notable feature of Figure 3 is the emission of $\mathrm{NH}_{3}$ at engine out temperatures $<300{ }^{\circ} \mathrm{C}$ (solid points). As the temperature in the TWC is lower than the engine out temperature, this suggests that $\mathrm{NH}_{3}$ reactions were occurring at much lower temperatures for the vehicle used in [19]. It could be that at lower temperatures a different formation process dominates, particularly at around the temperature where the TWC reaches light-off.

Tailpipe $\mathrm{NH}_{3}$ emission has been found to correlate well with engine out $\mathrm{CO}$ emission $\left(\mathrm{R}^{2}=0.75\right)$ [31], which is to be expected as CO is a reagent in Eqs. (2), (3), (6a). CO is also vital for the water-gas shift reaction, which is one route for providing the hydrogen required for Eq. (3), (4), (5). This implies that conditions favourable for the formation of $\mathrm{CO}$ (i.e. $\lambda<1$ ) are likely to produce significant amounts of $\mathrm{NH}_{3}$ over the TWC.

The correlation between emission of $\mathrm{NH}_{3}$ and engine out NO has been reported as substantially weaker; tests
W zależności od zawartości i rodzaju metali szlachetnych mogą być tworzone różne półprodukty, które mają następnie wpływ na dalsze reakcje powstawania $\mathrm{NH}_{3}$ w wyniku wielu reakcji chemicznych (reakcje (6a) $-(6 c))$.

Możliwe jest, iż pojedyncze reakcje mogą być podstawą procesu tworzenia $\mathrm{NH}_{3}$, a inne reakcje mogą zachodzić w innych warunkach, nawet w przypadku tego samego układu pojazdreaktor katalityczny-paliwo. Wielostopniowe reakcje mogą zachodzić równocześnie, powodując przyspieszenie tempa powstawania $\mathrm{NH}_{3}$. Jednakże pewien poziom temperatury musi być osiągnięty, zanim reakcja katalizy zacznie odgrywać znaczącą rolę w procesie, analogicznie do temperatury wymaganej do powstania $\mathrm{NH}_{3}$. Reakcje (2) i (3) mogą występować bez trudu powyżej $300{ }^{\circ} \mathrm{C}$, ale zależne jest to od składu spalin napływających z silnika do reaktora katalitycznego.

Według wielu autorów powstawaniu $\mathrm{NH}_{3}$ sprzyja spalanie „bogatej” mieszanki w silniku ZI [15, 17, 19, 30, 31, $33,34]$; prowadzone były również pomiary tej emisji w stanie pracy silnika przy zasilaniu ubogą mieszanką [19, 31]. Warunki pracy przy zasilaniu bogatą mieszanką oznaczają wzrost zapasów reagentów, takich jak CO i $\mathrm{HC}$ oraz zmniejszenie ilości dostępnego tlenu. Obecność wystarczającej ilości tlenu do przeprowadzenia reakcji jest sprzeczna z równaniem (3) [25]. Warunki powstałe przy zasilaniu silnika ubogą mieszanką oznaczają również, iż wodór nie jest tak reaktywny, więc przełamanie wiązań chemicznych $\mathrm{N} \equiv \mathrm{N}$ i $\mathrm{N}=\mathrm{O}$ jest bardziej skomplikowane [21]. Idealnymi warunkami powstawania $\mathrm{NH}_{3}$ wydają się: stan pracy silnika przy zasilaniu bogatą mieszanką, niedostatek tlenu przy wysokich temperaturach spalin silnika (rys. 3) - warunki te występują przy dużych obciążeniach, zwłaszcza w okresie gwałtownego i agresywnego przyspieszania. Niesprawny reaktor katalityczny, czy uszkodzona sonda $\lambda$ mogą powiększyć ten problem [26].

Interesującym zjawiskiem (rys. 3) jest emisja $\mathrm{NH}_{3}$ przy temperaturze gazów spalinowych w silniku $<300{ }^{\circ} \mathrm{C}$ (punkty oznaczone pełnymi kropkami). Skoro temperatura w reaktorze TWC jest niższa niż temperatura spalin wychodzących z silnika, to sugeruje to, iż reakcje $\mathrm{NH}_{3}$ mogą występować przy 


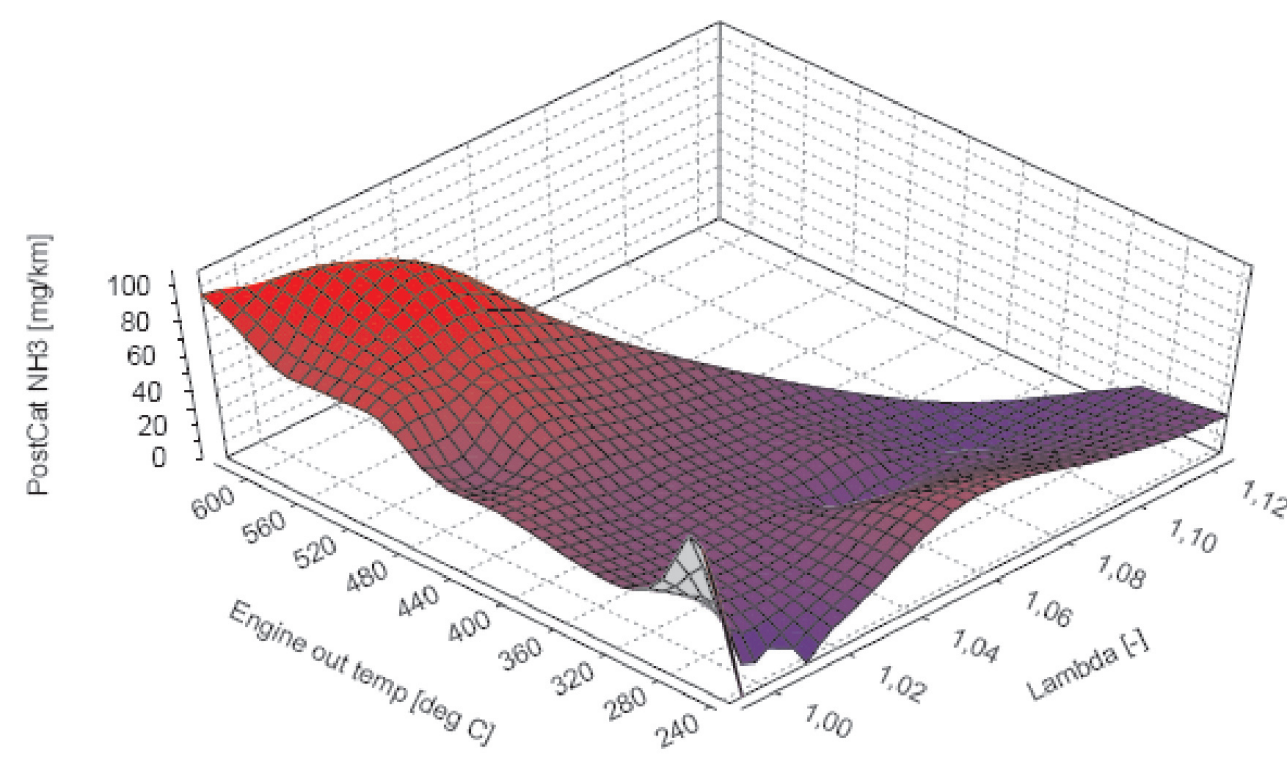

Fig. 4. Tailpipe $\mathrm{NH}_{3}$ emission as a function of both engine out temperature and $\lambda$ (data from [19]) Rys. 4. Emisja $\mathrm{NH}_{3}$ z uktadu wylotu spalin $w$ funkcji temperatury spalin silnika $i \lambda$ [19] dużo niższych temperaturach spalin [19]. Możliwe, iż przy niższych temperaturach inny mechanizm powstawania $\mathrm{NH}_{3}$ jest dominujący, szczególnie w okolicach temperatury początku działania reaktora TWC.

Emisja $\mathrm{NH}_{3}$ z układu wylotowego z silnika okazała się zależna od emisji CO w gazach spalinowych silnika $\left(\mathrm{R}^{2}=\right.$ $=0,75)[31]$, który może być reagentem w równaniach (2), (3), (6a). CO również może brać udział w reakcji zmiany wody w gaz, która jest jedynym sposobem dostarczenia wodoru do reakcji w równaniach (3), (4), (5). Powoduje to, iż warunki sprzyjające powstawaniu performed on several vehicles showed a maximum $\mathrm{R}^{2}$ value of 0.48 and an average $\mathrm{R}^{2}$ value of 0.27 [31]. However, a relatively strong correlation between engine out $\mathrm{NO}$ and tailpipe $\mathrm{NH}_{3}$ has been reported from tests on a single vehicle $\left(\mathrm{R}^{2}=0.78\right)[19]$. The dependence on engine out gas concentrations will depend on the particular reactions which dominate in the TWC fitted to the vehicle in question, and on the transient conditions, including $\lambda$.

The correlation between $\lambda$ and the $\mathrm{NH}_{3}$ emission factor for a particular vehicle has been reported as potentially significant but weak, with an $\mathrm{R}^{2}$ value of 0.3 [31] to 0.39 [19]. A surface plot of data presented in [19] is shown in Figure 4, showing significant variance in $\mathrm{NH}_{3}$ emission for the same value of $\lambda$.

Figure 4 shows the 'ramping up' of $\mathrm{NH}_{3}$ emission at higher engine loads (higher temperature; lower $\lambda$ ), but also that $\mathrm{NH}_{3}$ emission can take non-zero values when $\lambda>1$. Data presented in [19] show that emission is low to moderate at temperatures below $400{ }^{\circ} \mathrm{C}$.

Investigations into the effects of fuel chemistry on $\mathrm{NH}_{3}$ emission have primarily focussed on fuel sulphur content. Sulphur has been suspected to affect the formation of $\mathrm{NH}_{3}$ on a TWC. Sulphur is a potent inhibiting and poisoning agent for the surfaces of catalysts fitted to petrol- and Diesel-fuelled vehicles [3, 24, 29, 35] and this is one of the reasons why fuel sulphur content has been reduced by a factor of around thirty over the last few decades. The more active sites which are poisoned (or temporarily inhibited) with sulphur, the fewer active sites there would be for the catalyst to eliminate $\mathrm{CO}, \mathrm{NO}$ and $\mathrm{HC}$ (and produce $\mathrm{NH}_{3}$ ) [3]. In addition to obstruction of the active sites through steric effects, the sulphur oxide produced from the combustion of sulphur in the fuel appears to have a limiting
$\mathrm{CO}(\lambda<1)$, sprzyjają również powstawaniu znacznych ilości $\mathrm{NH}_{3}$ w reaktorze katalitycznym.

Zależność pomiędzy emisją $\mathrm{NH}_{3}$ i $\mathrm{NO}$ z silnika wydaje się wyraźnie mniejsza, przeprowadzone testy na kilku pojazdach pokazały, iż maksymalna wartość współczynnika $\mathrm{R}^{2}$ wynosiła 0,48, średnio osiągając wartość 0,27 [31]. Jednak względnie dużą zależność między emisją NO z silnika a emisją $\mathrm{NH}_{3}$ z układu wylotowego spalin z samochodu zauważono w teście dla pojedynczego pojazdu $\left(\mathrm{R}^{2}=0,78\right)$ [19]. Zależność stężenia gazów spalinowych wpływa częściowo na reakcje, które dominują w pojazdach z trójfunkcyjnymi reaktorami katalitycznymi i w nieustalonych warunkach, łącznie $\mathrm{z} \lambda$.

Zależność między $\lambda$ a emisją $\mathrm{NH}_{3}$ dla poszczególnych pojazdów okazała się potencjalnie znacząca, ale niezbyt duża - o wartości od 0,3 [31] do 0,39 [19]. Wykres przedstawiony w układzie przestrzennym, oparty na danych prezentowanych w [19], zaprezentowano na rys. 4: przedstawia on różne warianty emisji $\mathrm{NH}_{3}$ dla tej samej wartości $\lambda$.

Na rysunku 4 można zauważyć wyraźny wzrost emisji $\mathrm{NH}_{3}$ przy większych obciążeniach silnika (wyższe temperatury, mniejsza $\lambda$ ), ale także, że emisja $\mathrm{NH}_{3}$ ma wartości większe od zera przy wartościach $\lambda>1$. Dane przedstawione w [19] wskazują, iż emisja jest niska i raczej umiarkowana przy temperaturach mniejszych niż $400{ }^{\circ} \mathrm{C}$.

Badanie wpływu składu chemicznego paliwa na $\mathrm{NH}_{3}$ prowadzone były głównie pod kątem oceny wpływu zawartości siarki w paliwie. Siarka uznana jest za pierwiastek wspomagający powstawanie $\mathrm{NH}_{3}$ w trójfunkcyjnym reaktorze katalitycznym. Siarka jest potencjalnie hamującym reakcje katalizy i niszczącym środkiem dla powierzchni katalitycznych w reaktorach wykorzystanych w pojazdach 
effect on the production of hydrogen in the steam reforming and water-gas shift reactions [16]. Concerns were voiced regarding the effect of reduced sulphur concentrations in commercially available fuel [3]; some experimental data was presented to support this hypothesis (discussed in [4]). It was predicted that lowering fuel sulphur content would lead to elevated emissions of various unregulated compounds, including $\mathrm{NH}_{3}$ [16].

Laboratory tests using synthetic engine out gas streams over a catalyst indicate that the addition of $\mathrm{SO}_{2}$ causes $\mathrm{NH}_{3}$ production to rapidly decrease or even cease completely $[16,24]$. Other tests have found that the addition of $\mathrm{SO}_{2}$ merely pushes $\mathrm{NH}_{3}$ production to higher temperature ranges [32]. However, tests performed on multiple vehicles with relatively recent TWCs indicate no problems with low sulphur fuel [4] altering the sulphur content of the fuel by a factor of thirty can produce differences as small as only a few milligrams per mile [3, 4]. In fact, ammonia emission has been reported to be higher for fuels richer in sulphur, especially over a more aggressive driving cycle. Results presented by Bell and Yates [29] show greater $\mathrm{NH}_{3}$ emission from fuels richer in sulphur from a Euro 4 vehicle. The researchers also noted an increase in $\mathrm{HC}$ emission for these fuels, which may explain the increased production of $\mathrm{NH}_{3}$. The lowest $\mathrm{NH}_{3}$ results in [4] were obtained with a the fuel with the lowest sulphur content (5 ppm). In light of this, low sulphur petrol cannot rightly take the blame for $\mathrm{NH}_{3}$ emissions; it may even help to reduce them in certain cases.

Multiple observations that the high load conditions encountered during periods of rapid acceleration coincide with higher levels of $\mathrm{NH}_{3}$ emission have been formally studied $[31,33,36]$.

\section{Conclusions and further research}

SI vehicle with TWCs are an important source of ammonia in urban areas [28]. Virtually all on-road SI vehicles in Europe are now TWC-equipped, yet current and planned future EU legislation contains no emission limits for ammonia. The emission of ammonia is both problematic and undesirable, with the potential to significantly affect the PM load. Increasingly stringent legislation regarding air quality will push the issue of ammonia production from vehicles further up the air quality agenda.

The exact reactions which predominate within the catalyst are still somewhat unclear, but it is evident that reducing engine out emissions of unburned hydrocarbons, carbon monoxide and oxides of nitrogen would deprive the ammonia-forming reactions of their reagents. The potential impact of increases in engine out temperatures and $\mathrm{NO}_{\mathrm{x}}$ production which could result from downsizing of SI engines should be studied further. Catalyst design naturally focuses on the efficient elimination of regulated compounds, but greater consideration should be given to the influence of catalyst support metals, fluid dynamics, thermal inertia, etc. on the formation of unregulated species such as ammonia. The large variation between $\mathrm{NH}_{3}$ emission rates for different vehicles of the same emissions zasilanych benzyną i olejem napędowym [3, 24, 29, 35] i jest to jeden z powodów, dla którego zawartość siarki w paliwie została zmniejszona trzydziestokrotnie w ostatnich dekadach. Jeżeli jest więcej aktywnych miejsc reaktora zniszczonych na stałe lub czasowo przez siarkę, to pozostaje mniejsza liczba aktywnych miejsc, gdzie zachodzą reakcje utleniania i redukcji $\mathrm{CO}, \mathrm{NO}_{x}$ i $\mathrm{HC}$ (i produkcji $\mathrm{NH}_{3}$ ) [3]. Dodatkowo, jako przeszkoda efektu przestrzennego miejsc aktywnych, tlenki siarki powstałe w wyniku spalania siarki zawartej w paliwie mają ograniczający wpływ na produkcję wodoru $\mathrm{w}$ reakcjach reformingu parowego $\mathrm{i}$ zamiany wody w gaz [16]. Koncerny paliwowe zmuszane były do zmniejszenia ilości siarki w paliwie sprzedawanym na rynkach światowych, ponieważ siarka miała negatywny wpływ na funkcjonowanie reaktorów TWC [3, 4]. Efektem ubocznym tej decyzji było to, że obniżenie zawartości siarki w paliwie powodowało wzrost emisji innych, nieobjętych ograniczeniami przepisów dotyczących emisji, związków, włącznie $\mathrm{z} \mathrm{NH}_{3}$ [16].

Testy laboratoryjne z wykorzystaniem syntetycznych gazów spalinowych wprowadzanych przed reaktor katalityczny wskazują, iż dodatek $\mathrm{SO}_{2}$ powoduje gwałtowny spadek formowania się $\mathrm{NH}_{3}$, bądź też całkowite jego wstrzymanie. Inne testy wskazują, iż dodatek $\mathrm{SO}_{2}$ w spalinach ,przesuwa” formowanie $\mathrm{NH}_{3}$ do wyższych zakresów temperatur. Jednakże testy przeprowadzone na różnych pojazdach pokazały, iż z całą pewnością obecne trójfunkcyjne reaktory katalityczne nie stwarzają problemów podczas zasilania nisko siarkowym paliwem, zmniejszona trzydziestokrotnie zawartość siarki powoduje jedynie małe różnice rzędu kilku miligramów na milę [3, 4]. Faktycznie, emisja amoniaku wydaje się wyższa dla paliw bogatszych w siarkę, zwłaszcza przy bardziej agresywnych cyklach jezdnych. Wyniki zaprezentowane przez Bella i Yatesa [29] pokazują znaczący wzrost emisji $\mathrm{NH}_{3}$ dla paliwa bogatego w siarkę, w pojazdach spełniających normę Euro 4. Autorzy zauważyli również wzrost emisji HC dla tego typu paliw, co może wytłumaczyć równoczesny wzrost emisji $\mathrm{NH}_{3}$. Mniejszą emisję $\mathrm{NH}_{3} \mathrm{w}$ [4] zauważono dla paliw o najmniejszej zawartości siarki. W świetle tych wniosków paliwo nisko siarkowe nie może być uznane za główną przyczynę wzrostu emisji $\mathrm{NH}_{3}$, przeciwnie, może nawet powodować zmniejszenie tej emisji w pewnych warunkach pracy silnika.

Badania prowadzone przez wiele ośrodków wykazały, że w warunkach dużych obciążeń silnika samochodowego, które występują podczas gwałtownego przyspieszania, następuje jednocześnie wyższy poziom emisji $\mathrm{NH}_{3}[31$, $33,36]$

\section{Podsumowanie i dalsze badania}

Pojazdy z silnikami ZI i trójfunkcyjnymi reaktorami katalitycznymi są znaczącym źródłem emisji $\mathrm{NH}_{3}$ na terenach zurbanizowanych i w miastach [28]. W rzeczywistości każdy pojazd na drogach Europy z silnikiem ZI wyposażony jest obecnie w trójfunkcyjny reaktor katalityczny TWC. Aktualnie obowiązujące i planowane przepisy dotyczące emisji związków szkodliwych w Unii Europejskie dla tego 
standard underlines the need for further research and measuring techniques that give accurate, repeatable results. The use of dilution tunnels and sampling bags is not be an appropriate experimental technique for the measurement of $\mathrm{NH}_{3}$ [15]; special analysers are required to measure $\mathrm{NH}_{3}$ (and other RNCs) directly from the exhaust. Additionally, legislative modal driving cycles may not be 'aggressive' enough to reveal realistic $\mathrm{NH}_{3}$ emission factors.

\section{Nomenclature/Skróty i oznaczenia}

$\lambda$ lambda; ratio of the air-to-fuel ratio to the stoichiometric ratio/współczynnik Lambda, stosunek powietrza do paliwa

$\mathrm{CO}$ carbon monoxide/tlenek węla

$\mathrm{CO}_{2}$ carbon dioxide/dwutlenek węgla

EU European Union/Unia Europejska

HC Hydrocarbons/węglowodory

NO Nitrogen monoxide, nitric oxide/tlenek azotu (I)

$\mathrm{NO}_{2} \quad$ Nitrogen dioxide/dwutlenek azotu, tlenek azotu (IV)

$\mathrm{NO}_{\mathrm{x}}$ Oxides of nitrogen $\left(\mathrm{NO}+\mathrm{NO}_{2}\right)$ /tlenki azotu $\left(\mathrm{NO}+\mathrm{NO}_{2}\right)$

$\mathrm{N}_{2} \mathrm{O} \quad$ Nitrous oxide/podtlenek azotu

$\mathrm{NH}_{3} \quad$ Ammonia/amoniak

PM Particulate matter/cząstka stała

ppm Parts per million/czesści na milion

$\mathrm{R}^{2} \quad \mathrm{R}$-squared least mean squares value for goodness of fit/ kwadrat wartości zgodności rozkładów

RNC Reactive nitrogen compounds/reaktywne związki azotu

SCR Selective catalytic reduction/selektywna redukcja katalityczna

SI Spark ignition/zapłon iskrowy

TWC Three-way catalyst/trójfunkcyjny reaktor katalityczny

UNECE United Nations Economic Commission for Europe/Europejska Komisja Gospodarcza Narodów Zjednoczonych (EKG ONZ)

Paper reviewed/Artykuł recenzowany typu pojazdów nie zawierają limitów emisji amoniaku. Problem emisji amoniaku jest bardzo niepokojący i niepożądany z powodu potencjalnego wpływu na formowanie się cząstek stałych. Wzrastające wymagania odnośnie do jakości powietrza prawdopodobnie spowodują, iż zjawisko powstawania amoniaku w układach wylotowych pojazdów znajdzie odzwierciedlenie w przepisach dotyczących jakości powietrza.

Dokładne reakcje, które dominują w reaktorach katalitycznych są nadal nie w pełni poznane, ale oczywiste jest, że zmniejszenie emisji w spalinach takich związków, jak HC, $\mathrm{CO}$ i NO może ograniczyć procesy formowania amoniaku przez zmniejszenie ilości podstawowych substratów, które w tych reakcjach biorą udział. Potencjalny wpływ zwiększania temperatury spalin i powstawania $\mathrm{NO}_{x}$, spowodowany zmniejszeniem wymiarów gabarytowych i objętości skokowej silników ZI z jednoczesnym turbodoładowaniem (downsizing), powinien być szczegółowo sprawdzony. Konstruktorzy reaktorów katalitycznych skupiają się na efektywności eliminacji związków ograniczonych przepisami prawnymi, ale powinni poświęcić również więcej uwagi na wpływ stosowanych metali szlachetnych, dynamikę przepływu gazów przez reaktor, bezwładność cieplną i inne, na tworzenie się dodatkowych związków szkodliwych i toksycznych, nieograniczonych przepisami prawnymi, takich jaki amoniak. Olbrzymia rozbieżność pomiędzy poziomem emisji $\mathrm{NH}_{3}$ dla różnych pojazdów spełniających te same standardy emisyjne podkreśla potrzebę prowadzenia dalszych badań i rozwoju techniki pomiarowej, dającej bardziej dokładne i powtarzalne wyniki. Używanie obecnie tuneli rozcieńczających czy specjalnych worków na próbki nie jest odpowiednią techniką eksperymentalną pomiaru $\mathrm{NH}_{3}$; wymagane jest opracowanie specjalnego przyrządu do pomiaru emisji $\mathrm{NH}_{3}$ i RNC bezpośrednio z układu wylotowego pojazdu. Dodatkowo cykle jezdne opisane w przepisach emisyjnych nie charakteryzują się wystarczająco dużymi przyspieszeniami pojazdu, aby zasymilować emisję $\mathrm{NH}_{3}$ na poziomie zbliżonym do występującego w czasie rzeczywistego ruchu pojazdów na terenach miejskich i zurbanizowanych.

\section{Bibliography/Literatura}

[1] Whitehead J. et al.: Seasonal and Diurnal Variation in Atmospheric Ammonia in an Urban Environment Measured Using a Quantum Cascade Laser Absorption Spectrometer. Water Air Soil Pollution, 183:317-329, 2007.

[2] Harkins J., Nicksic S.: Ammonia in Auto Exhaust. Environmental Science and Technology, Vol. 1, Number 9, 1967, 751-752.

[3] Durbin T. et al.: The Effect of Fuel Sulfur on $\mathrm{NH}_{3}$ and Other Emissions from 2000-2001 Model Year Vehicles - CRC Project No. E-60 submitted to CONCAWE, 2003. Available online: http://www.crcao.com
[4] Durbin T. et al.: The effect of fuel sulfur on $\mathrm{NH}_{3}$ and other emissions from 2000-2001 model year vehicles. Atmospheric Environment 38, 2004, 2699-2708.

[5] Erisman J., Schaap M.: The need for ammonia abatement with respect to secondary PM reductions in Europe. Environmental Pollution 129, 2004,159-163.

[6] EU MEMO/07/571. Questions and Answers on the new directive on ambient air quality and cleaner air for Europe. 12.12.2007. Available online: http://www.europa.eu

[7] Heeb N. et al.: Trends of NO-, $\mathrm{NO}_{2}-$, and $\mathrm{NH}_{3}$-emissions from gasoline-fuelled Euro 3- to Euro 4-passenger cars. Atmospheric Environment 42, 2004, 2543-2554. 
[8] Whitehead J. et al.: Hourly Concentrations of Ammonia During the Winter in Manchester, UK, Related to Traffic and Background Sources. American Meteorological Society Abstract. Available online: http://ams.confex.com

[9] Kim Y. et al.: Formation of secondary aerosols over Europe: comparison of two gas-phase chemical mechanisms. Atmos. Chem. Phys., 2001, 11, 583-598.

[10] Pavlovic R.T. et al.: Ammonia emissions, concentrations and implications for particulate matter formation in Houston, TX. Atmospheric Environment, Volume 40, Supplement 2, 2006 , 538-551.

[11] Martin R.: Personal communication. 24 June 2010.

[12] Cape J. et al.: Concentrations of ammonia and nitrogen dioxide at roadside verges, and their contribution to nitrogen deposition. Environmental Pollution. 2004, Vol. 32, 3, 469-478.

[13] Cape J. et al.: Evidence for changing the critical level for ammonia. Environmental Pollution, 2009, Vol. 157, Issue 3, 1033-1037.

[14] Directive 2001/81/EC of the European Parliament and of the Council of 23 October 2001 on national emission ceilings for certain atmospheric pollutants. Official Journal of the European Communities, L 309/22, 27.11.2001.

[15] Heeb N. et al.: Correlation of hydrogen, ammonia and nitrogen monoxide (nitric oxide) emissions of gasoline-fueled Euro-3 passenger cars at transient driving. Atmospheric Environment 40, (2006), 3750-3763.

[16] Mejia-Centeno I.et al.: Effect of low-sulfur fuels upon $\mathrm{NH}_{3}$ and $\mathrm{N}_{2} \mathrm{O}$ emission during operation of commercial three-way catalytic converters. Topics in Catalysis Vols., 2007, 42-43.

[17] Protocol to the 1979 Convention on Long-Range Transboundary Air Pollution to abate Acidification, Eutrophication and Ground-level Ozone. United Nations Economic Commission for Europe, 1999. Available online: http://www.unece.org

[18] European Commission: Science for Environment Policy News Service, Special Issue 4, 2008. Is better regulation of ammonia emissions required? Available online: http://www.europa.eu

[19] Heeb N. et al.: Three-way catalyst-induced formation of ammonia - velocity- and acceleration-dependent emission factors. Atmospheric Environment 40, 2006, 5986-5997.

[20] TNO report 06.OR.PT.023.2/NG (2006). Euro VI technologies and costs for Heavy Duty vehicles. Available online: http:// europa.eu

[21] Torkkell K.: Proceedings of The First International Exhaust Emissions Symposium, Bielsko-Biała, Poland, May 2010. ISBN: 978-83-931383-0-2.

[22] Hill L.: Proceedings of The First International Exhaust Emissions Symposium, Bielsko-Biala, Poland, May 2010. ISBN: 978-83-931383-0-2.

[23] Matsumoto R. et al.: Comparison of Ammonium Deposition Flux at Roadside and at an Agricultural Area for Long-term Monitoring: Emission $\mathrm{NH}_{3}$ from Vehicles. Water, Air, \& Soil Pollution, 2006, 173, 355-371.

Mr. Piotr Bielaczyc, DEng. - head of the Engine Research Department, BOSMAL Automotive Research and Development Institute Ltd in Bielsko-Biała.

Dr inż. Piotr Bielaczyc - kierownik Zakładu Badań Silników, Instytut Badań i Rozwoju Motoryzacji BOSMAL Sp. z o.o., Bielsko-Biała.

e-mail:piotr.bielaczyc@bosmal.com.pl
[24] Kean A. et al.: On-Road Measurement of Ammonia and Other Motor Vehicle Exhaust Emissions. Environmental Science \& Technology, 2000, Vol.34, No. 17.

[25] Miyamoto A. et al.: Automotive Exhaust Emissions Control Using the Three-way Catalyst System. Ind. Eng. Chem. Prod. Res. Dev.,1979, Vol. 18, No. 2.

[26] Sutton M. et al.: Ammonia emissions from non-agricultural sources in the UK. Atmospheric Environment 34, 2000, 855869.

[27] Durbin T.D.: Estimates of the emission rates of ammonia from light-duty vehicles using standard chassis dynamometer test cycles. Atmospheric Environment, 2002, Vol. 36, 9, 14751482.

[28] Perrino C. et al.: Gaseous ammonia in the urban area of Rome, Italy and its relationship with traffic emissions. Atmospheric Environment, 36/34, 2002, 5385-5394.

[29] Bell A., Yates A.: An Evaluation of the Speciated Exhaust Emissions Associated with South African Gasolines in an EU4 Vehicle, 2008, SAE technical paper: 2008-01-1769.

[30] Defoort M. et al.: The effect of air-fuel ratio control strategies on nitrogen compound formation in three-way catalysts. International Journal of Engine Research, Vol. 5, Number $1 /$ 2004, 115-122.

[31] Huai T. et al.: Investigation of the formation of $\mathrm{NH}_{3}$ Emissions as a Function of Vehicle Load and Operating Condition, 2003, Available online: http://www.epa.gov

[32] Cant N. et al.: Nitrous oxide formation during the reaction of simulated exhaust streams over rhodium, platinum and palladium catalysts. Applied Catalysis B: Environmental, 1998, 17, 63-73.

[33] Jiménez-Palacios J.: Understanding and Quantifying Motor Vehicle Emissions with Vehicle Specific Power and TILDAS Remote Sensing. Ph.D. thesis, 1999, Available online: http:// www.mit.edu

[34] Li H. et al.: Investigation of Regulated and Non-Regulated Cold Start Emissions using a Euro 3 SI Car as a Probe Vehicle under Real World Urban Driving Conditions, 2008, SAE Technical Paper: 2008-01-2428.

[35] Kozak M., Merkisz J.: The Mechanics of Fuel Sulphur Influence on Exhaust Emission from Diesel Engines. TEKA Kom. Mot. Energ. Roln., 2005, 5, 96-106.

[36] Huai T. et al.: Vehicle Specific Power Approach to Estimating On-Road NH3 Emissions from Light-Duty Vehicles. Environ. Sci. Technol. 2005, 39, 9595-9600.

Mr. Antoni Świątek, DSc., DEng. - head of the BOSMAL Automotive Research and Development Institute Ltd in Bielsko-Biała.

Dr hab. inż. Antoni Światek - dyrektor Instytutu Badań i Rozwoju Motoryzacji BOSMAL Sp. z o.o., Bielsko-Biala.

e-mail: antoni.swiatek@bosmal.com.pl

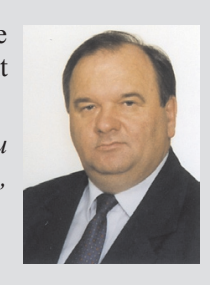

Mr. Joseph Woodburn, MSc. - researcher at the Engine Research Department, BOSMAL Automotive Research and Development Institute Ltd in Bielsko-Biała.

Mgr inż. Joseph Woodburn - inżynier ds. badań w Zaktadzie Badań Silników, Instytut Badań i Rozwoju Motoryzacji BOSMAL Sp. z o.o., Bielsko-Biała. 